\title{
High Mercury Concentrations of European Perch (Perca fluviatilis) in Boreal Headwater Lakes with Variable History of Acidification and Recovery
}

\author{
Martti Rask (D) Tommi Malinen • Mikko Olin · Kari Nyberg • \\ Jukka Ruuhijärvi $\cdot$ Kimmo K. Kahilainen $\cdot$ Matti Verta $\cdot$ Jussi Vuorenmaa • \\ Tarja-Riitta Blauberg • Lauri Arvola
}

Received: 2 March 2021 / Accepted: 12 August 2021 / Published online: 9 September 2021

(C) The Author(s) 2021

\begin{abstract}
High dissolved organic carbon and low $\mathrm{pH}$ are often associated with elevated mercury content of fish in boreal lakes, but less is known about the fish mercury dynamics in lakes recovering from acidification stress. We measured total mercury concentration (THg) in muscle of European perch (Perca fluviatilis) and evaluated the overall correlation with environmental and growth variables in 24 boreal headwater lakes in the 2010s. We found negative correlations of length-corrected perch $\mathrm{THg}$ with lake $\mathrm{pH}$ and perch growth, but no correlation with dissolved organic carbon. The main emphasis in the present study was focused to a subset of ten lakes
\end{abstract}

M. Rask $(\bowtie) \cdot$ T. Malinen · K. K. Kahilainen · L. Arvola Lammi Biological Station, University of Helsinki, FI-16900 Lammi, Finland

e-mail: martti.rask@helsinki.fi

T. Malinen

KVVY Tutkimus Oy, Patamäenkatu 24,

FI-33900 Tampere, Finland

M. Olin · J. Ruuhijärvi

Natural Resources Institute (LUKE), Helsinki, Finland

\section{K. Nyberg}

Department of Environmental Sciences, University

of Helsinki, Helsinki, Finland

M. Verta $\cdot$ J. Vuorenmaa

Finnish Environment Institute (SYKE), Helsinki, Finland

T.-R. Blauberg

Ministry of the Environment, Helsinki, Finland in southern Finland with known perch $\mathrm{THg}$ during severe acidification in the 1980-1990s. The comparison of perch $\mathrm{THg}$ concentrations in the 2010s with values determined in the 1980-1990s showed a sharp increase in most acidic lakes where the perch populations suffered from severe acid stress in the 1980s. This increase was attributed to growth condensation caused by sharp decrease in perch growth during recovery of reproduction capacity and the consequent increases in population densities of perch. Our results highlight the importance of perch growth rate and population density for understanding the variability of fish $\mathrm{Hg}$ in boreal headwater lakes, where recovery from acidification can lead to higher mercury concentration of fish in certain cases.

Keywords $\mathrm{THg} \cdot \mathrm{Low} \mathrm{pH} \cdot$ Dissolved organic carbon - Growth dilution · Population density · Reproduction failure

\section{Introduction}

Acidification of poorly buffered boreal and alpine lakes in the 1900s due to air pollutants resulted in population declines of several sensitive fish species in northern Europe, the USA and Canada (Almer et al., 1974; Baker et al., 1993; Hesthagen et al., 1999). Tammi et al. (2003) estimated with a postal survey based on the Fennoscandian water chemistry data (Henriksen et al., 1998) that acidification-induced 
reproduction failures and subsequent declines and extinctions of fish populations occurred in more than 10,000 Nordic lakes (Finland, Norway, Sweden). The estimate for Finland was 1850 fish populations, out of which 410 were affected perch populations. This is in line with estimates of critical levels of acidification for common fish species and modelled number of lakes that acidified over those levels in Finland (Rask et al., 1995). A gillnet survey of 80 lakes indicated low fish status in strongly acidified lakes of southern Finland (Rask \& Tuunainen, 1990). These observations were ascertained with more detailed studies, including mark and recapture studies of perch populations in lakes in different degree of acidification (Lappalainen et al., 1988) and field and laboratory experiments on survival of perch embryos in acidic waters (Rask et al., 1990; Vuorinen et al., 1992). Studies of growth responses in remaining perch in affected lakes indicated exceptionally high growth rate in some lakes in conditions of abundant macroinvertebrate food availability with no food competition in the scarce perch populations (Nyberg et al., 1995; Raitaniemi et al., 1988; Rask et al., 2014a). High mercury concentrations have been often reported in fish from acidified lakes (Greenfield et al., 2001; Richman et al., 1988), but several studies have shown that the impacts of acidification or sulphate deposition on the dynamics of mercury are complex (Bloom et al., 1991; Wyn et al., 2010; Braaten et al., 2020; Watras et al., 2020).

International agreements to reduce sulphur emissions led to decreased acid deposition and a subsequent gradual increase of lake buffering capacity and pH (Stoddard et al., 1999; Vuorenmaa \& Forsius, 2008) and associated recovery of fish reproduction (Fjellheim et al., 2007; Keller et al., 2007; Nyberg et al., 1995). As a consequence of decreased sulphur deposition, acidity of soil and ionic strength of soil water have decreased acting through chemicallycontrolled organic matter solubility in catchment soils, and dissolved organic carbon (DOC) loads from catchments to lakes have increased resulting in higher DOC concentrations in lake waters (Monteith et al., 2007; Vuorenmaa et al., 2006). Recent changes in climatic conditions, such as increased precipitation and discharge, are exerting a greater influence on variation and increasing DOC concentrations in surface waters (de Wit et al., 2016; Zwart et al., 2017).
Increasing DOC levels, often termed lake browning, have several important consequences in lake ecosystems including decreased light penetration in water, increased bacterial activity, reduced fish production and increased hypolimnetic anoxia (e.g. Arvola et al., 2014; Creed et al., 2018; Rask et al., 2014b). Because DOC compounds form complexes with metals, including $\mathrm{Hg}$, the mercury load from catchments to lakes has increased which may result in increased mercury in fish in some lakes (Braaten et al., 2014a; Driscoll et al., 1995; Hongve et al., 2012). However, the mercury content of fish muscle is the outcome of a combination of deposition, environmental and biotic variables, and those are often region- and lake-specific. Recovery of boreal lakes from acidification provides an opportunity to evaluate the underlying factors behind mercury content of fish muscle (Braaten et al., 2020; Hrabik \& Watras, 2002; Watras et al., 2006).

Atmospheric mercury originates from both natural and anthropogenic sources, of which the latter has been increasingly dominant since the industrial revolution (Chen et al., 2018; Pacyna et al., 2010; Streets et al., 2011). After the Minamata Bay accident, there was increasing interest in measuring fish mercury content globally, including in the industrial regions of northern Europe and North America. In Finland, fish mercury concentrations up to $5-6 \mathrm{mg} \mathrm{kg}^{-1}$ (ww) were recorded due to industrial pollution in the late 1960s (Häsänen \& Sjöblom, 1968). Since then, the fish $\mathrm{Hg}$ concentrations in Nordic countries have decreased due to the ban of the use of $\mathrm{Hg}$ as a slimecide in the pulp and paper industry and due to the considerable reductions in $\mathrm{Hg}$ discharges from chloralkali plants (e.g. Åkerblom et al., 2014; Lodenius, 1991; Verta, 1990a). In a Finnish fish mercury survey in the early 2000s, a significant decreasing trend of pike (Esox lucius L.) mercury was recorded in lakes subject to industrial pollution in earlier decades (Paloheimo, 2005). However, in headwater lakes, where mercury mainly originates from atmospheric deposition to the catchment and to the lake surface, the $\mathrm{Hg}$ concentrations of pike had remained at similarly high levels as recorded in earlier surveys (Paloheimo, 2005). Taking into account the decrease in mercury emissions from European sources during the early 1990s (Travnikov et al., 2012), records of the decreases in surface sediment $\mathrm{Hg}$ concentrations (Mannio, 2001) and reductions in mercury deposition since the early $1990 \mathrm{~s}$ 
(Ilyin et al., 2015; Ruoho-Airola et al., 2014; Wängberg et al., 2010), lowered fish mercury concentrations could have been expected (Braaten et al., 2019).

Mercury bioaccumulates in organisms and biomagnifies in aquatic food webs in the form of methylmercury (MeHg) which may enter lakes through precipitation, watershed runoff and in-lake and catchment methylation of inorganic Hg (Morel et al., 1998; Ullrich et al., 2001). The relative importance of these different sources varies depending on the amount of deposition, lake type and catchment hydrology (Rudd, 1995). Eckley et al. (2005) suggested that inlake methylation of $\mathrm{Hg}$ can be more important than $\mathrm{MeHg}$ transport from the drainage basin, in spite of the dominance of wetlands in lake catchments. However, intensive forestry-related land use in boreal catchments may increase both methylation hot-spots as well as run-off of historical wetland mercury via machinery wheel tracks and ditching activities (Ahonen et al., 2018; Eklöf et al., 2018).

Mercury in water is predominately methylated by sulphate reducing bacteria (SRB) under anoxic conditions (Choi et al., 1994; Ullrich et al., 2001). SRB occur commonly in the chemocline of oxygen-stratified headwater lakes in Finland (Arvola et al., 1992; Karhunen et al., 2013) resulting in increased $\mathrm{MeHg}$ concentrations below the oxycline of the lakes (Verta et al., 2010). The biomagnification potential of $\mathrm{MeHg}$ in aquatic food webs is much higher than that of total mercury $(\mathrm{THg})$, illustrated by an increasing proportion of $\mathrm{MeHg}$ along food chains from phytoplankton c. $15 \%$, to zooplankton c. $30 \%$ to fish c. $90-95 \%$ (Watras et al., 1995, 1998). In fish muscle tissue, THg can be efficiently used as a proxy for $\mathrm{MeHg}$ concentration (Downs et al., 1998; Lescord et al., 2018).

In addition to differences in lake and catchment characteristics and in-site specific mercury dynamics (Parkman \& Meili, 1993; Richman et al., 1988; Simonin et al., 2008), the structure and function of food webs affect the bioaccumulation of mercury into fish (Futter, 1994; Rask et al., 1996; Yu et al., 2011). Increasing trophic position and pelagic energy sources are often related to higher mercury content of fish (Kahilainen et al., 2016; Karimi et al., 2016). This is the case with the European perch, Perca fluviatilis L. (Braaten et al., 2014b; Kraemer et al., 2012), which is a generalist carnivore characterized by ontogenetic diet shift from zooplankton to macroinvertebrates and fish (Allen, 1935; Estlander et al., 2010). Given the rapid changes in food web structure in recovering acidified lakes, including population and growth responses of fish (Keller et al., 2007; Nyberg et al., 2010; Rask et al., 2014a), further increase in the variability in fish mercury concentrations can be expected.

We studied water chemistry, perch growth and perch mercury content in 24 small acid-sensitive boreal headwater lakes in southern Finland to test the main underlying correlations. We predicted a negative correlation of fish $\mathrm{THg}$ content with $\mathrm{pH}$ and growth rate, but a positive correlation with DOC (Driscoll et al., 1995; Watras et al., 1995). In 10 of the lakes, perch mercury concentrations had been measured during the 1980-1990s (Metsälä \& Rask, 1989), and from these lakes with variable history of acidification and recovery, we predicted decreased $\mathrm{THg}$ in perch muscle as $\mathrm{pH}$ has increased and deposition of sulphate and mercury decreased (Ruoho-Airola et al., 2014).

\section{Material and Methods}

\subsection{Study Area}

For the present study, we sampled 24 natural headwater lakes for perch THg. All the lakes are in southern Finland, mainly in conservation or nature management areas with limited land-use activity. The catchment areas of the lakes are relatively small and comprise a mixture of coniferous and deciduous boreal forest and peatland or rocky landscape. The lakes are small with surface area between 1 and 43 ha, maximum depth 3-19 m, and altitude 16-156 m above sea level (Table 1). Water quality data were obtained from the databases of the Department of Environmental Sciences and Lammi Biological Station, University of Helsinki, and from the Finnish Environment Institute (http://www.syke.fi/open_data). The lakes are acidic with a $\mathrm{pH}$-range $4.6-6.4$ and alkalinity from -0.05 to $0.1 \mathrm{mmol} \mathrm{l}^{-1}$ during the autumn turn over. Water colour and DOC ranged from 15-395 mg Pt $\mathrm{l}^{-1}$ and 2.9-24.5 $\mathrm{mg}^{-1}$, respectively (Table 1 ). Sixteen of the 24 lakes have a known history of acidification and recovery from acidification (Forsius et al., 1990; Mannio, 2001; Vuorenmaa \& Forsius, 2008), browning (Vuorenmaa et al., 2006), fish responses to acidification and recovery (Lappalainen et al., 1988; 


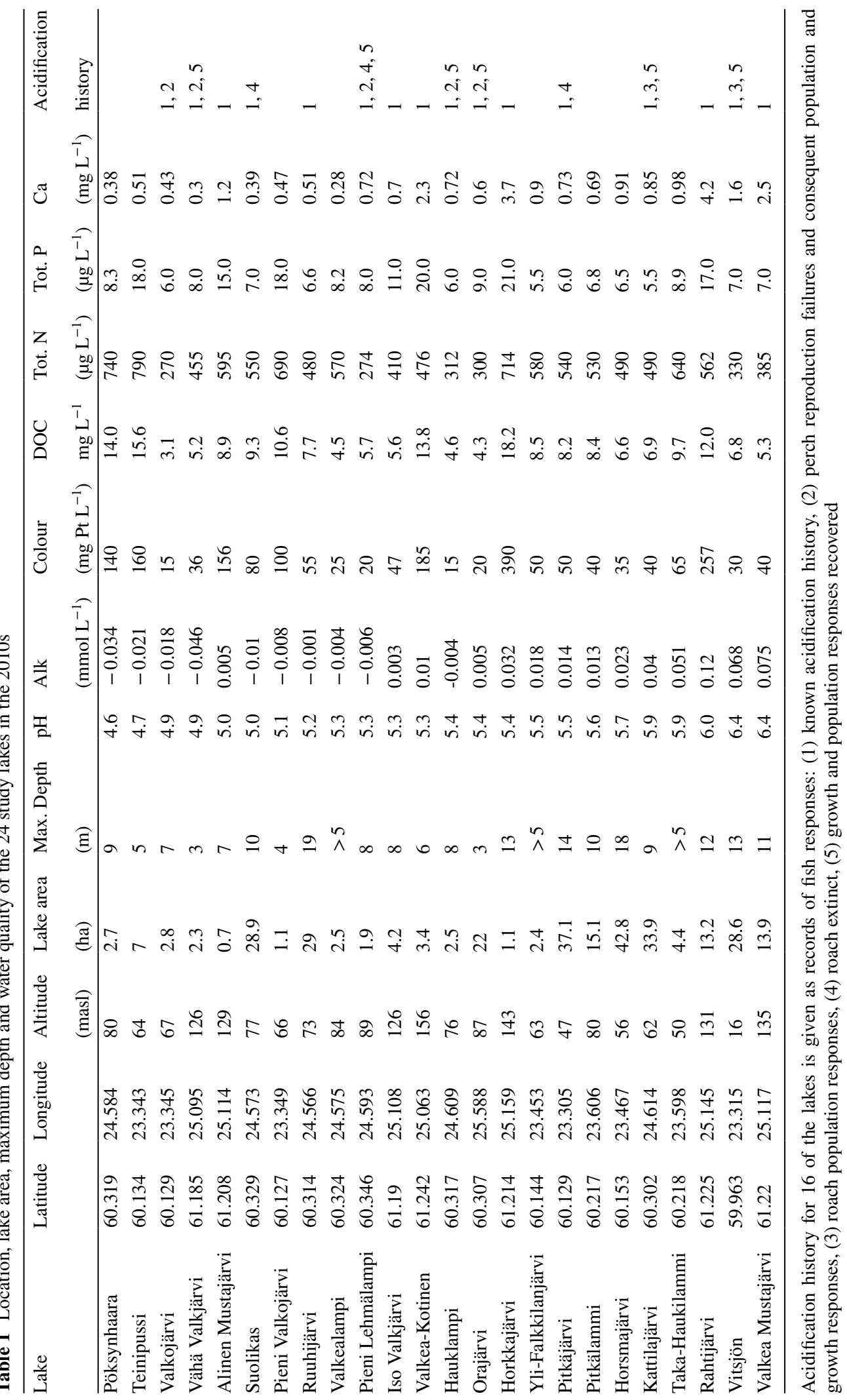


Tammi et al., 2004) and growth responses of perch (Nyberg et al., 2010; Raitaniemi et al., 1988; Rask et al., 2014a). For ten lakes, perch mercury concentrations were also available from the years of strong acidification in 1980s and 1990s (Metsälä \& Rask, 1989). Four of these lakes suffered from severe acidification in those years, including perch population and growth responses (Raitaniemi et al., 1988; Rask et al., 2001), whereas the rest of the lakes acidified only slightly with no perch population responses (Metsälä \& Rask, 1989).

\subsection{Sampling of Fish}

Fish for mercury analyses were caught during 2009-2014 with wire traps, gillnets, and hook and line (11 to 56 perch per lake, 664 in total, Table 2). Total length $(\mathrm{mm})$ and weight $(\mathrm{g})$ were measured for each fish. Samples for mercury analyses were taken from dorsal white muscle and frozen $\left(-20^{\circ} \mathrm{C}\right)$ until analysed. Opercular bones of all fishes were taken for age determination. As fish growth rate is known to affect mercury bioaccumulation (Göthberg, 1983; Rask et al., 1996; Verta, 1990b), a simple proxy of perch growth for each lake was calculated by dividing the mean length of sampled perch by their mean age (mean annual length increment). For the ten lakes with perch mercury data from two periods, 1980-1990s and 2010s, the $\mathrm{Hg}$ concentrations in the 2010s were related to the changes in the mean annual length increment of perch.

\subsection{Mercury Analyses}

THg concentrations of the perch muscle samples were determined in the Department of Environmental Sciences, University of Helsinki, using a Milestone

Table 2 Lake-specific mean total length, weight, age, growth and measured THg values of perch in the 24 lakes of the study

\begin{tabular}{|c|c|c|c|c|c|c|c|c|c|}
\hline \multirow[t]{2}{*}{ Lake } & \multirow{2}{*}{$\begin{array}{l}\text { Length } \\
(\mathrm{cm})\end{array}$} & \multirow{2}{*}{$\begin{array}{l}\text { Weight } \\
(\mathrm{g})\end{array}$} & \multirow{2}{*}{$\begin{array}{l}\text { Age } \\
(y r)\end{array}$} & \multirow{2}{*}{$\begin{array}{l}\text { Growth } \\
\left(\mathrm{cm} \mathrm{yr}^{-1}\right)\end{array}$} & \multicolumn{2}{|c|}{ THg measured $\left(\mu \mathrm{g} \mathrm{g}^{-1}\right)$} & \multirow{2}{*}{$\begin{array}{l}\mathrm{THg}\left(\mu \mathrm{g} \mathrm{g}^{-1}\right) \\
15 \mathrm{~cm} \text { stand }\end{array}$} & \multirow[t]{2}{*}{$\mathrm{N}$ of perch } & \multirow{2}{*}{$\begin{array}{l}\mathrm{N} \text { of fish } \\
\text { species }\end{array}$} \\
\hline & & & & & average & range & & & \\
\hline Pöksynhaara & 16.3 & 47.6 & 8.3 & 2.0 & 0.91 & $0.36-1.63$ & 0.88 & 31 & 2 \\
\hline Teinipussi & 14.6 & 34.9 & 6.0 & 2.5 & 0.52 & $0.10-1.13$ & 0.54 & 33 & 2 \\
\hline Valkojärvi & 19.2 & 94.6 & 6.4 & 3.0 & 1.23 & $0.54-2.65$ & 1.07 & 35 & 1 \\
\hline Vähä Valkjärvi & 17.4 & 42.7 & 9.0 & 1.9 & 0.85 & $0.57-1.17$ & 0.73 & 11 & 1 \\
\hline Alinen Mustajärvi & 12.3 & 18.5 & 3.0 & 4.1 & 0.21 & $0.12-0.27$ & 0.19 & 12 & 2 \\
\hline Suolikas & 17.1 & 66.1 & 6.9 & 2.5 & 0.9 & $0.36-2.50$ & 0.76 & 56 & 3 \\
\hline Pieni Valkojärvi & 19.4 & 84.5 & 8.3 & 2.3 & 0.67 & $0.13-1.76$ & 0.74 & 41 & 1 \\
\hline Ruuhijärvi & 17.2 & 57.0 & 5.6 & 3.1 & 0.42 & $0.20-0.77$ & 0.36 & 36 & 3 \\
\hline Valkealampi & 17.7 & 63.6 & 5.3 & 3.3 & 0.86 & $0.23-1.71$ & 0.66 & 31 & 1 \\
\hline Pieni Lehmälampi & 17.8 & 58.8 & 6.0 & 3.0 & 0.81 & $0.27-1.39$ & 0.58 & 12 & 1 \\
\hline Iso Valkjärvi & 14.4 & 32.2 & 4.0 & 3.6 & 0.18 & $0.12-0.39$ & 0.18 & 12 & 2 \\
\hline Valkea-Kotinen & 14.6 & 32.7 & 4.0 & 3.7 & 0.31 & $0.16-0.61$ & 0.28 & 12 & 2 \\
\hline Hauklampi & 22.1 & 123.0 & 8.0 & 2.8 & 0.86 & $0.48-1.55$ & 0.74 & 12 & 1 \\
\hline Orajärvi & 15.7 & 35.8 & 6.0 & 2.6 & 0.71 & $0.43-0.87$ & 0.66 & 10 & 1 \\
\hline Horkkajärvi & 12.4 & 20.9 & 9.0 & 1.4 & 0.56 & $0.23-0.80$ & 0.76 & 12 & 1 \\
\hline Yli-Falkkilanjärvi & 17.3 & 58.3 & 5.4 & 3.2 & 0.81 & $0.36-1.41$ & 0.73 & 32 & 2 \\
\hline Pitkäjärvi & 18.3 & 75.5 & 5.9 & 3.1 & 0.88 & $0.33-1.78$ & 0.69 & 47 & 3 \\
\hline Pitkälammi & 20.8 & 113.4 & 5.3 & 4.0 & 0.47 & $0.18-1.15$ & 0.21 & 50 & 3 \\
\hline Horsmajärvi & 17.4 & 77.5 & 4.7 & 3.7 & 0.32 & $0.14-0.84$ & 0.26 & 45 & 4 \\
\hline Kattilajärvi & 14.5 & 31.9 & 4.4 & 3.3 & 0.33 & $0.06-0.76$ & 0.35 & 30 & 5 \\
\hline Taka-Haukilammi & 15.9 & 54.2 & 5.9 & 2.7 & 0.51 & $0.16-1.39$ & 0.47 & 33 & 5 \\
\hline Rahtijärvi & 13.0 & 29.9 & 4.0 & 3.3 & 0.34 & $0.19-0.71$ & 0.35 & 12 & 6 \\
\hline Vitsjön & 20.5 & 116.6 & 6.7 & 3.1 & 0.68 & $0.15-2.01$ & 0.38 & 45 & 4 \\
\hline Valkea Mustajärvi & 15.6 & 50.5 & 3.0 & 5.2 & 0.21 & $0.15-0.25$ & 0.20 & 12 & 2 \\
\hline
\end{tabular}

Length corrected (to $15 \mathrm{~cm}$ ) $\mathrm{THg}$ values, number of sampled perch and number of fish species per lake are also given 
DMA-80 Direct Mercury Analyzer (Milestone $\mathrm{GmbH}$, Germany) and results given as $\mathrm{THg}\left(\mathrm{mg} \mathrm{kg}^{-1}\right)$ in wet weight of fish (ww). Certified reference materials, DORM-4 fish protein (National Research Council, Canada, mercury concentration of $0.410 \mathrm{mg} \mathrm{kg}^{-1}$ ) or cod muscle, CRM 422 (EC Community Bureau of Reference, mercury concentration of $0.559 \mathrm{mg} \mathrm{kg}^{-1}$ ), were used for quality assurance of the analyses at the beginning and end of each run. Two replicate subsamples (ww 0.1-0.25 g) from each fish sample were analysed, and the mean concentrations of duplicates were used in subsequent data analyses.

For comparisons of lakes in 2009-2014, the measured THg concentrations of individual perch $(n>30)$ were standardized to $15 \mathrm{~cm}$ total length using lakespecific linear regression models. For lakes with a smaller fish sample $(n \leq 30)$, a simple linear relationship between mercury concentration and fish length was assumed. For 10 lakes, historical mercury data during acidification had been measured with a Perkin Elmer Coleman MAS-50 analyzer (Metsälä \& Rask, 1989). For quality control, see Verta (1990a) and Rask et al. (2007).

The effects of time period (1983-1994 vs. 2013-2014), lake and perch length (covariate) and their interactions on $\mathrm{THg}$ concentration was tested with ANCOVA. To normalize variances, $\mathrm{Hg}$ concentration and perch length were ln-transformed and results presented as geometric mean values. Tukey-Kramer's test was used for pairwise comparisons. Results were considered significant, when $p<0.05$.

\section{Results}

\subsection{Perch THg Content and Correlations with Environmental and Biotic Variables During the 2010s}

The measured average concentration of $\mathrm{THg}$ in perch from 24 lakes varied between 0.18 and $1.23 \mathrm{mg} \mathrm{kg}^{-1}$ (ww) (Table 2). Individual perch $\mathrm{THg}$ ranged from 0.06 to $2.65 \mathrm{mg} \mathrm{Hg} \mathrm{kg}^{-1}$ and concentrations $>1 \mathrm{mg}$ $\mathrm{Hg} \mathrm{kg}^{-1}$ were detected from 14 lakes. The highest $\mathrm{THg}$ concentrations of $>2 \mathrm{mg} \mathrm{kg}^{-1}$ were measured from four large (total length $31-36 \mathrm{~cm}$ ) and old (10-11 years) individuals in three different lakes (Table 2).
Relating the length-corrected average $\mathrm{THg}$ concentrations of perch to lake water quality parameters resulted in significant correlation with $\mathrm{pH}$ (Fig. 1a) and alkalinity, but not with water colour, DOC (Fig. 1b), total nutrients or calcium (Table 3). THg had a significant inverse relation to the average annual length increment of perch $(r=0.7, p<0.001$, Fig. 1c).

Among the 16 lakes with known fish population responses to acidification, the highest perch $\mathrm{THg}$ concentrations were recorded in the lakes that had suffered from severe fish population damage in the 1980s, including reproduction failures and changes in population structure and growth of perch and/or disappearance of roach (Rutilus rutilus L.). The present data contained seven such lakes with mean perch $\mathrm{THg}$ concentration $0.71-1.07 \mathrm{mg} \mathrm{kg}^{-1}$. In the nine lakes of known fish population status without acidificationinduced perch population responses in the 1980s, the mean $\mathrm{THg}$ concentration was significantly lower, between 0.21 and $0.68 \mathrm{mg} \mathrm{kg}^{-1}(t=-6.92, d f=14$, $p<0.001$, Fig. 1d).

\subsection{Perch THg Content During Acidification and Recovery}

A comparison of perch $\mathrm{THg}$ concentrations in the 2010s with those measured in ten lakes in the 1980-1990s (Table 4) indicated increased levels in seven out of ten examined lakes. The four clearest lakes Hauklampi, Pieni Lehmälampi, Orajärvi and Vähä Valkjärvi (water colour $<50 \mathrm{mg} \mathrm{Pt} \mathrm{L}{ }^{-1}$ ) showed the highest increase in perch $\mathrm{THg}$, up to $>3 \times$ from the 1980-1990s to the 2010s (Fig. 2). These four lakes suffered from severe acidification-induced perch population crash in the 1980s (Fig. 3) but have since recovered with a $\mathrm{pH}$ increase of ca. 0.5 units, whereas in three humic lakes, the alkalinity even decreased due to increased organic acidity in the course of browning of the lakes (Table 5). In five lakes, the increase in perch mercury was statistically significant (Tukey-Kramer's test, Table 6), and only one of them (Valkea-Kotinen) was humic (water colour $>50 \mathrm{mg}$ $\mathrm{Pt} \mathrm{L}^{-1}$ ). Clear water Lake Iso Valkjärvi was the only lake with a statistically significant decrease in perch THg.

There was a significant negative correlation between the perch THg concentrations in the 2010s and the change in average annual length increment 
a

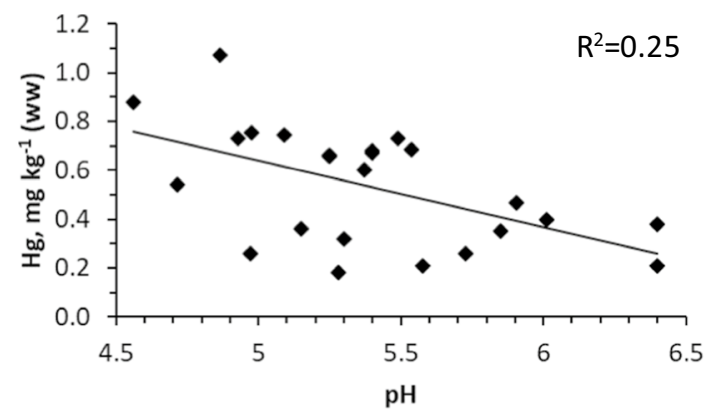

C

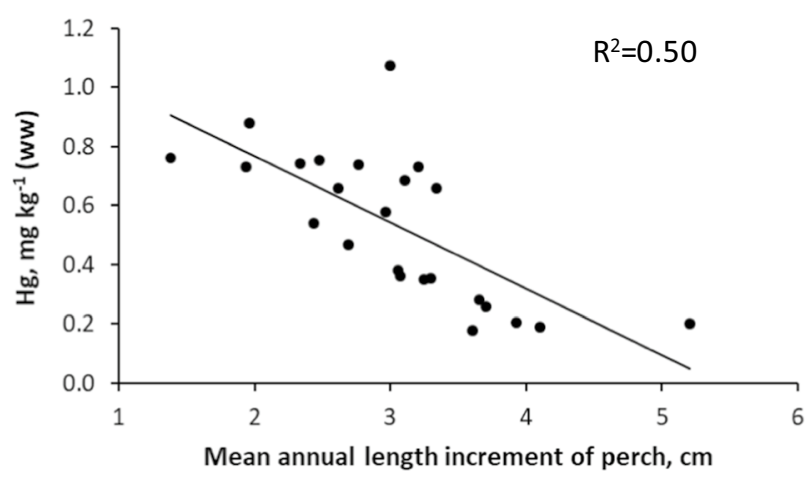

Fig. 1 The relation of $15 \mathrm{~cm}$ length-standardized $\mathrm{THg}$ concentration of perch to a lake $\mathrm{pH}, \mathbf{b}$ DOC and $\mathbf{c}$ mean annual length increment of the fish in 24 lakes. d The perch $\mathrm{THg}$ (mean $\pm S D, 15 \mathrm{~cm}$ length-standardized) in lakes with known b

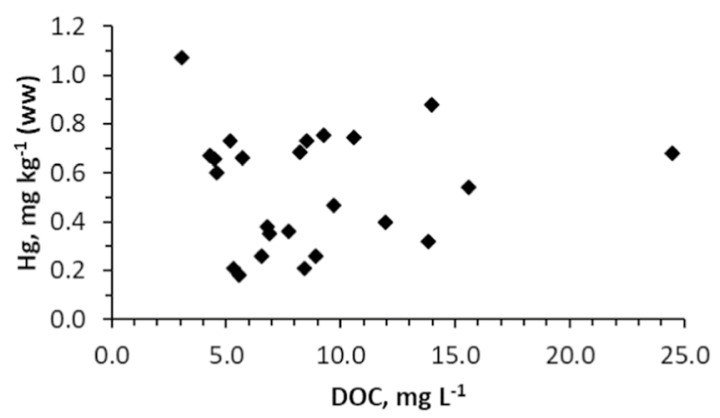

d

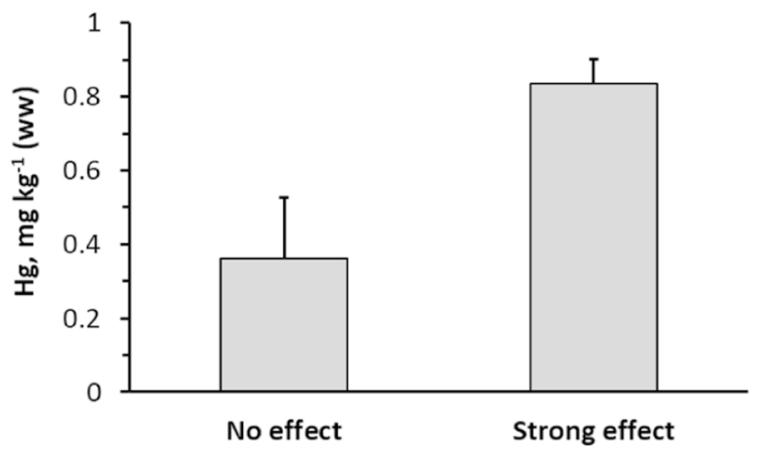

history of acidification-induced fish responses. No effect $=$ no perch population responses to acidification recorded $(n=9)$. Strong effect $=$ reproduction failures and changes in population structure and growth of perch or disappearance of roach $(n=7)$
Table 3 Correlations (r) between length-corrected $\mathrm{THg}$ values of perch and water quality parameters in the 24 study lakes

\begin{tabular}{lcccccccc}
\hline & Perch THg & \multicolumn{1}{c}{$p H$} & Alk & Colour & DOC & Tot. N & Tot. $P$ & $C a$ \\
\hline Perch THg & 1.00 & & & & & & & \\
pH & $\mathbf{- 0 . 5 2}$ & 1.00 & & & & & & \\
Alk & $-\mathbf{0 . 5 0}$ & 0.88 & 1.00 & & & & & \\
Colour & -0.01 & -0.11 & 0.25 & 1.00 & & & & \\
DOC & 0.01 & -0.20 & 0.09 & 0.87 & 1.00 & & & \\
Tot. N & 0.06 & -0.30 & -0.07 & 0.60 & 0.79 & 1.00 & & \\
Tot. P & -0.11 & -0.19 & 0.10 & 0.83 & 0.74 & 0.51 & 1.00 & \\
Ca & -0.30 & 0.51 & 0.76 & 0.73 & 0.47 & 0.10 & 0.55 & 1.00 \\
\hline
\end{tabular}

Significant correlations in bold between the two sampling periods, 1980-1990s and 2010s ( $r=0.7, p<0.05$, Fig. 4). In those lakes, where the annual length increment had decreased, $\mathrm{THg}$ was $0.3-0.8 \mathrm{mg} \mathrm{kg}^{-1}$, whereas $\mathrm{THg}$ was below $0.3 \mathrm{mg} \mathrm{kg}^{-1}$ in the lakes where the annual length increment had increased.

\section{Discussion}

The present study clearly demonstrated high perch mercury concentrations in poorly buffered headwater lakes in southern Finland. The concentrations recorded in the present study were 4-5 fold higher than in eight eutrophicated lakes in the same region 
Table 4 ANCOVA results to test the effects of time period (1983-1994 vs. 2013-2014), lake and perch length (covariate) and their interactions on perch $\mathrm{THg}$-concentration

\begin{tabular}{lllrr}
\hline Effect & No. df & Den df & $F$ Value & $p>F$ \\
\hline Lake & 9 & 182 & 3.32 & $<0.001$ \\
Time period & 1 & 182 & 61.89 & $<0.001$ \\
Perch length & 1 & 182 & 23.21 & $<0.001$ \\
Lake x Time period & 9 & 182 & 18.09 & $<0.001$ \\
Perch length x Lake & 9 & 182 & 4.31 & $<0.001$ \\
\hline
\end{tabular}

(Marttila \& Roikonen, 2016) with known fish status (Olin et al., 2006). Furthermore, in the present study, the perch mercury concentrations exceeded the EQS (Ecological Quality Standard) limit of the European Union (EU) Water Framework Directive (0.20-0.25 $\mu \mathrm{g} \mathrm{g}^{-1}$ (ww) in Finland depending on the water colour) in 21 out of 24 lakes (88\%) and the upper limit for human consumption of fish in EU $\left(0.5 \mu \mathrm{g} \mathrm{g}^{-1}\right)$ in 15 lakes (63\%). Perch THg content was negatively correlated with $\mathrm{pH}$, whereas there was no correlation with DOC. In fact, growth rate seems to be a more important determinant of $\mathrm{THg}$ content in perch than any single environmental variable. This highlights the importance of understanding fish lifehistory traits and population dynamics when explaining changes in THg content.

\subsection{Perch $\mathrm{THg}$ Is Mainly Related to $\mathrm{pH}$ and Growth Rate}

Increased concentrations of mercury in water (Braaten et al., 2018; Watras et al., 1995), sediments (Kainz \& Lucotte, 2006; Mannio, 2001) and fish (Braaten et al.,
2020; Porvari, 1998) have been linked to amount of dissolved organic matter in lakes. Consequently, the recent rise of DOC concentrations of lakes has been considered to be the major reason for increased mercury concentrations in the fish of formerly acidified lakes (Gandhi et al., 2014; Hongve et al., 2012; Wyn et al., 2010). In the present study, this is not the case as the increases in perch mercury were highest in the clearest lakes that also remained clear (DOC $<5 \mathrm{mg}$ $\mathrm{L}^{-1}$ ) from the 1980s to the 2010s. The lack of significant correlations between perch $\mathrm{THg}$ and DOC was not surprising in the acid-sensitive headwaters of the present study, whereas significant negative correlations between lake $\mathrm{pH}$ or alkalinity and fish mercury concentrations have been reported in many related studies (Björklund et al., 1984; Greenfield et al., 2001; Verta et al., 1990).

One possible explanation for increased perch $\mathrm{THg}$ might have been enhanced bioavailability of mercury through increased methylation by sulphate-reducing bacteria (SRB) in anoxic conditions (Eckley et al., 2005; Ullrich et al., 2001). The importance of oxygen stratification to $\mathrm{MeHg}$ dynamics and perch mercury concentrations was shown in a lake-scale thermocline manipulation experiment during 2004-2007 (Arvola et al., 2017; Forsius et al., 2010) where deepening of the thermocline and consequent decrease in the area of oxycline of a small lake resulted in a decrease of epilimnetic $\mathrm{MeHg}$ concentration in the water (Verta et al., 2010), followed by a decrease of THg in small perch (Rask et al., 2010). However, as two of the four lakes with highest perch mercury increase between the 1980s and 2010s (Orajärvi and Vähä Valkjärvi) are shallow (maximum depth 4.5 and $3 \mathrm{~m}$, respectively) and lack an anoxic hypolimnion,
Fig. 2 Length-standardized $(15 \mathrm{~cm}) \mathrm{THg}$ concentrations (geometric mean $\pm 95 \%$ c.l.) of perch in ten lakes in the 1980-1990s and in the 2010s. Lakes listed along increasing water colour measured in the 2010s (Table 5)

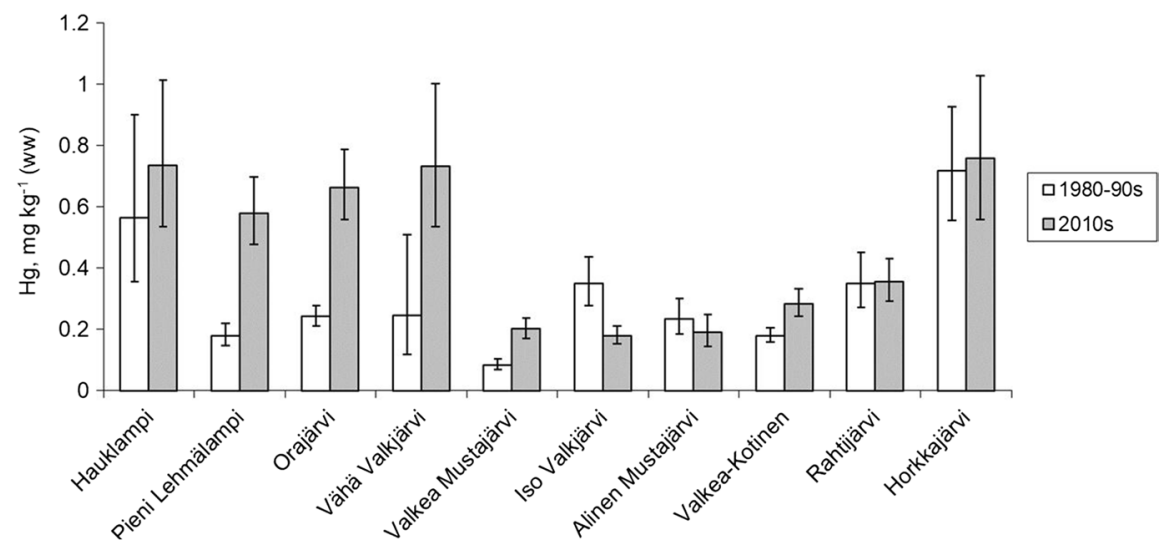


Fig. 3 a Length frequency distribution of perch in L. Orajärvi during 1985-2007 derived from standard gillnet catches. Black symbols refer to the years of highest acidification impact on the populations, open symbols to the years of recovery. $\mathbf{b}$ Back-calculated growth of the year-classes 1964-2006 for perch in L. Orajärvi $(n=641)$. The earliest year-classes 1964-1968, indicated with solid grey line, were born before the highest acidification impact. The year classes 1972-1990 with broken line are from the years of highest impact on perch population, and those from 1991 and onwards with solid black line are from years of recovery. Redrawn from Rask et al. (2014a)
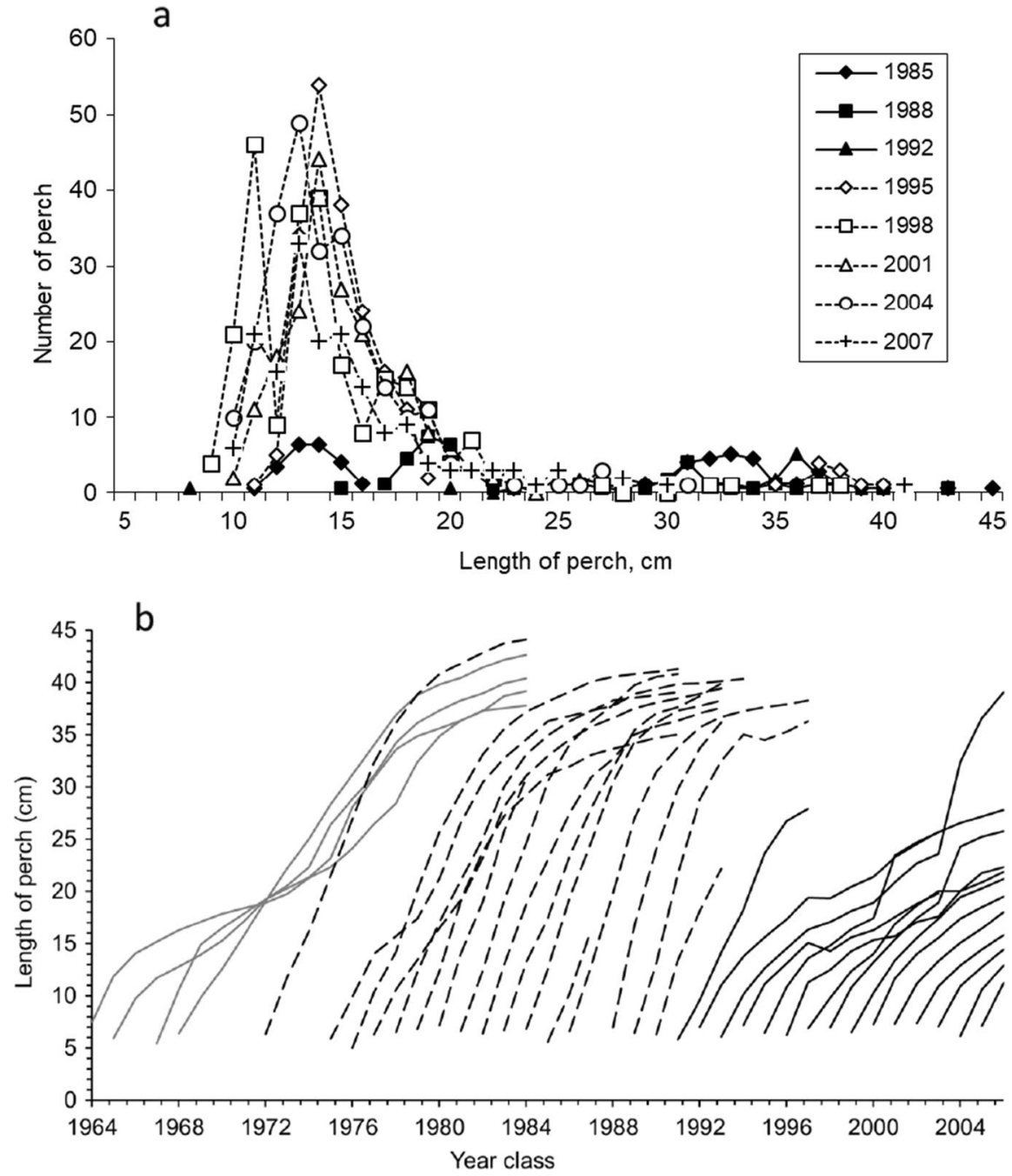

Table 5 Water quality in ten lakes sampled for perch mercury in two time periods, 1980-90 s and 2010s

\begin{tabular}{|c|c|c|c|c|c|c|c|c|c|c|c|c|}
\hline \multirow[b]{2}{*}{ Lake } & \multicolumn{2}{|l|}{$\mathrm{pH}$} & \multicolumn{2}{|c|}{$\begin{array}{l}\text { Alkalinity ( } \mu \mathrm{eq} \\
\left.\mathrm{L}^{-1}\right)\end{array}$} & \multicolumn{2}{|c|}{$\begin{array}{l}\text { Colour (mg Pt } \\
\mathrm{L}^{-1} \text { ) }\end{array}$} & \multicolumn{2}{|c|}{$\mathrm{DOC}\left(\mathrm{mg} \mathrm{L}^{-1}\right)$} & \multicolumn{2}{|c|}{ Ptot $\left(\mu \mathrm{g} \mathrm{L}^{-1}\right)$} & \multicolumn{2}{|c|}{$\mathrm{N}$ of perch } \\
\hline & $1980 \mathrm{~s}$ & $2010 \mathrm{~s}$ & $1980 \mathrm{~s}$ & $2010 \mathrm{~s}$ & $1980 \mathrm{~s}$ & $2010 \mathrm{~s}$ & $1980 \mathrm{~s}$ & $2010 \mathrm{~s}$ & $1980 \mathrm{~s}$ & $2010 \mathrm{~s}$ & $1980 \mathrm{~s}$ & $2010 \mathrm{~s}$ \\
\hline Vähä Valkjärvi & 4.47 & 4.93 & -46 & -9 & 5 & 36 & 4.3 & 5.2 & 8.0 & 8.0 & 7 & 11 \\
\hline Pieni Lehmälampi & 4.67 & 5.25 & -16 & -6 & 15 & 20 & 4.6 & 5.7 & 7.0 & 8.0 & 10 & 12 \\
\hline Hauklampi & 4.72 & 5.37 & -11 & -4 & 12.5 & 15 & 4.5 & 4.6 & 9.0 & 6.0 & 5 & 12 \\
\hline Orajärvi & 4.9 & 5.4 & -30 & 5 & 5 & 20 & 1.5 & 4.3 & 6.0 & 9.0 & 25 & 10 \\
\hline Iso Valkjärvi & 4.98 & 5.28 & 2 & 3 & 77 & 47 & 6.5 & 5.6 & 18.0 & 11.0 & 6 & 12 \\
\hline Valkea-Kotinen & 5.3 & 5.3 & 5 & 10 & 122 & 185 & 11.3 & 13.8 & 20.0 & 20.0 & 20 & 12 \\
\hline Alinen Mustajärvi & 5.45 & 4.97 & 20 & 5 & 90 & 156 & 6.9 & 8.9 & 22.0 & 15.0 & 5 & 12 \\
\hline Horkkajärvi & 5.54 & 5.4 & 58 & 32 & 290 & 390 & 13.0 & 18.2 & 18.0 & 21.0 & 5 & 12 \\
\hline Rahtijärvi & 5.99 & 6.01 & 120 & 104 & 216 & 257 & 10.7 & 12.0 & 26.0 & 17.0 & 5 & 12 \\
\hline Valkea Mustajärvi & 6.44 & 6.4 & 50 & 75 & 40 & 40 & 5.3 & 5.3 & 10.0 & 7.0 & 7 & 12 \\
\hline
\end{tabular}

Number of fish samples also given 
Table 6 Results of TukeyKramer's test on withinlake differences in perch mercury concentrations between the the two time periods

\begin{tabular}{lccccccr}
\hline Lake & Year 1 & Year 2 & Estimate & SE & DF & t Value & Pr >|t| \\
\hline Hauklampi & 1985 & 2013 & 0.264 & 0.159 & 182 & 1.65 & 0.100 \\
Pieni Lehmälampi & 1986 & 2013 & 1.165 & 0.119 & 182 & 9.82 & $<\mathbf{0 . 0 0 1}$ \\
Orajärvi & 1994 & 2014 & 1.004 & 0.111 & 182 & 9.07 & $<\mathbf{0 . 0 0 1}$ \\
Vähä Valkjärvi & 1986 & 2013 & 1.098 & 0.260 & 182 & 4.22 & $<\mathbf{0 . 0 0 1}$ \\
Valkea Mustajärvi & 1983 & 2013 & 0.881 & 0.134 & 182 & 6.6 & $<\mathbf{0 . 0 0 1}$ \\
Iso Valkjärvi & 1983 & 2013 & -0.667 & 0.143 & 182 & -4.67 & $<\mathbf{0 . 0 0 1}$ \\
Alinen Mustajärvi & 1983 & 2013 & -0.210 & 0.190 & 182 & -1.1 & 0.271 \\
Valkea Kotinen & 1992 & 2013 & 0.458 & 0.103 & 182 & 4.46 & $<\mathbf{0 . 0 0 1}$ \\
Rahtijärvi & 1983 & 2013 & 0.010 & 0.178 & 182 & 0.06 & 0.954 \\
Horkkajärvi & 1983 & 2013 & 0.057 & 0.174 & 182 & 0.33 & 0.744 \\
\hline Significant & & & & & & &
\end{tabular}

Significant differences in bold the occurrence and role of SRB in MeHg dynamics is probably marginal in these two lakes. Further, reduced sulphate deposition, which has resulted in decreases of lake $\mathrm{SO}_{4}$ concentrations (Nyberg et al., 2010), may have limited the activity of SRB in lakes (Braaten et al., 2020). Thus, changes in inlake methylation of mercury by SRB do not explain the increases of perch mercury concentrations in our lakes.

The significant inverse relation between the length increment and mercury concentration of perch in the present study emphasizes the importance of growth patterns of fish. Fast growing individuals are known to exhibit growth dilution of $\mathrm{Hg}$ in fish, and thus effective fishing has been suggested as a method to decrease the $\mathrm{Hg}$ levels in fish and the fish consumption risk of humans (Göthberg, 1983; Verta, 1990b).

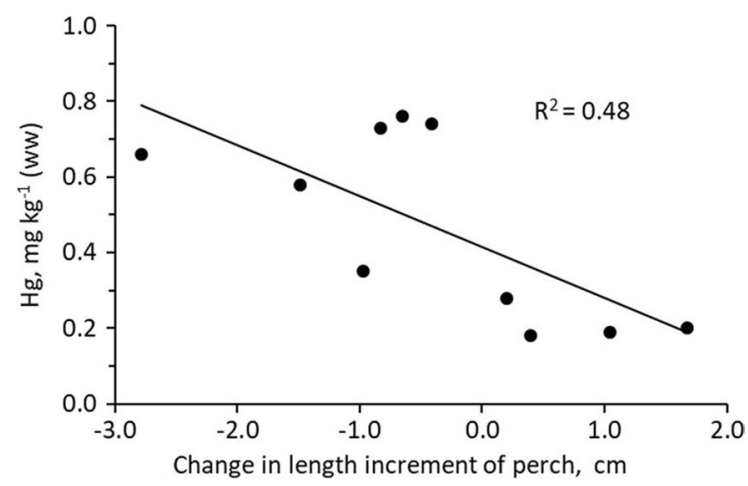

Fig. 4 The relation between perch THg in the 2010s $(15 \mathrm{~cm}$ length-standardized) and the change of average annual length increment of perch from the $1980-1990$ s to the 2010 s in ten lakes

\subsection{Perch THg Content Increased During the Recovery of Strongly Acidified Lakes}

In some of our strongly acidified lakes, the growth of perch was very fast in the 1980s due to very low population densities caused by repeated reproduction failures and relaxing of resource competition (Lappalainen et al., 1988; Raitaniemi et al., 1988). This was particularly evident in Lake Orajärvi with 3-year-old perch of $>20 \mathrm{~cm}$ and 5-year-olds close to $30 \mathrm{~cm}$ in total length (Nyberg et al., 1995; Rask et al., 2014a).

Consequently, an apparent reason for relatively low perch $\mathrm{THg}$ in those years was the growth dilution, i.e. muscle grew faster than the fish accumulated mercury (e.g. Göthberg, 1983; Keva et al., 2017). The increased availability of macroinvertebrate food apparently enabled the increase in perch growth (Nyberg et al., 2010) and may also have contributed to the growth dilution of mercury. This is because littoral macroinvertebrates have been shown to be less efficient transporters of $\mathrm{Hg}$ up food chains than crustacean zooplankton (Kahilainen et al., 2016; Karimi et al., 2016). From the beginning of the 1990s, the reproduction of perch recovered and resulted in high population density followed by a steep decrease in perch growth (Nyberg et al., 1995; Rask et al., 2014a). This explained the increased perch $\mathrm{THg}$ concentration, possibly also contributed to by increased use of zooplankton food by perch of new abundant yearclasses after a sharp decrease of macroinvertebrates (Nyberg et al., 2010). Thus, an "inverse growth dilution", i.e. mercury condensation via starvation, took place (Keva et al., 2017). This also happened in two other formerly strongly acidified lakes (Lake Pieni Lehmälampi, Lappalainen et al., 1988 and Lake Vähä 
Valkjärvi, Rask et al., 2001) although the decrease of perch growth was not as steep as in Lake Orajärvi. In Lake Hauklampi (Raitaniemi et al., 1988); there was almost no difference in perch growth between the two sampling periods and the difference in mercury concentrations remained nonsignificant. In L. Valkea Mustajärvi a significant increase in the perch $\mathrm{THg}$ took place, but this cannot be explained neither by water quality changes nor by growth responses.

In Lake Valkea-Kotinen, the only humic lake with significant increase in perch $\mathrm{THg}$, the increase in organic carbon load (Vuorenmaa et al., 2014) may have contributed to the $\mathrm{Hg}$ load and the perch $\mathrm{THg}$. In this lake, being a monitoring site in the International Cooperative Programme on Integrated Monitoring of Air Pollution Effects on Ecosystems (UNECE ICP IM), the increased DOC was connected to the decrease of general productivity of the lake during a 20-year monitoring period (Arvola et al., 2014), but the growth responses of perch were slight in comparison to the strongly acidified lakes of the present study (Rask et al., 2014b). In L. Horkkajärvi, the most humic of the ten lakes, the slight increase in perch THg may be connected to the organic load but be as well due to natural variation.

Lake Iso Valkjärvi was the only lake with a statistically significant decrease in perch $\mathrm{THg}$ concentrations between the two sampling periods. However, there was a liming experiment in the lake in the early 1990s (Rask et al., 1996) and an experimental size-selective removal of perch in 2008-2011 (Olin et al., 2017) that both have probably affected the $\mathrm{Hg}$ dynamics in the lake. Further, a sudden collapse of most of the perch population in the reference half of the lake took place during the liming experiment in autumn 1992 (Rask et al., 1996) resulting in a fivefold increase in length growth of remaining perch and subsequent growth dilution of $\mathrm{THg}$ to half of that before the fish kill (Rask et al., 2007). The fish kill affected also lower trophic levels of the lake which was seen in increased abundance of macroinvertebrates like phantom midge larvae (Chaoborus sp.) and water boatmen (Corixidae sp.), but in decreased abundance of cladoceran zooplankton, apparently due to increased predation by macroinvertebrates (Rask et al., 1996). The increased availability of benthic macroinvertebrates apparently enabled the increase in perch growth and may have contributed to the growth dilution of perch $\mathrm{THg}$ also in this case. The size-selective removal fishing in 2008-2011 may also have affected the decrease of perch $\mathrm{THg}$ in Iso Valkjärvi as it temporarily decreased the biomass and increased the growth-rate of perch, changed the population structure towards smaller and younger individuals (Olin et al., 2017), and increased the proportion of macroinvertebrates in the diet of perch (Nurminen et al., 2018).

Climate change has resulted in a $0.4{ }^{\circ} \mathrm{C}$ increase in mean air temperature per decade and a 17 day addition per decade in the duration of ice free period of lakes in the study region (Jylhä et al., 2014). This should have an overall positive growth and reproduction response for perch and should lower the mercury content via growth dilution. However, it seems that intra-specific density dependent processes and lowered water transparency of lakes due to browning are more important determinants of growth than warming (Rask et al., 2014b). Increasing precipitation and air temperature, followed by hydrological changes with increasing runoff and elevated leaching of substances from catchments to lakes, browning of lake waters and effects on lake temperature, stratification and oxygen dynamics (Couture et al., 2015; Vuorenmaa et al., 2014), will continuously affect the mercury dynamics in catchments and lakes (Ahonen et al., 2018). Time series analyses have shown that responses in fish $\mathrm{Hg}$ over decades are often non-linear in relation to linear decreases of mercury emissions and deposition (Gandhi et al., 2014; Braaten et al., 2019; Wang et al., 2019; Watras et al., 2019, 2020). This has been attributed to legacy mercury and changing biogeochemical processes. Climate change has become the most prevalent contributor to this divergence (Wang et al., 2019), and regular oscillation of water levels in lakes connected to large-scale atmospheric circulation patterns are also important (Watras et al., 2020). Taking into account all this, changes in the bioaccumulation of $\mathrm{Hg}$ and wide variations of mercury concentrations in biota of aquatic food webs up to fish are expected to continue in the future.

To conclude, the results of this study clearly indicated the occurrence of high perch mercury concentrations in poorly buffered boreal headwater lakes. The negative correlation of fish $\mathrm{THg}$ with lake $\mathrm{pH}$ and growth of perch was as predicted, but the lack of correlation with DOC was not. Given the complex effects of climate change processes and decreased atmospheric $\mathrm{SO}_{4}$ deposition on mercury dynamics in 
lakes and their catchments, we believe that chemical recovery of the lakes from acidification and consequent changes in the food web, including reproduction of perch, increase in population density and drastic decreases in growth of perch, were the main mechanisms leading to increases in perch mercury in formerly strongly acidified lakes of the present study, counter to our original prediction. Our results suggest that growth rate and population density of fish should always be taken account of when assessing changes in mercury content in muscle.

Acknowledgements The authors thank all persons involved in collecting fish samples and analysing mercury over the years. No specific funding was received for conducting this study, but the work was done in connection with environment research projects at Lammi Biological Station and the Department of Biological and Environmental Sciences of the University of Helsinki, the Finnish Environment Institute and the Finnish Game and Fisheries Research Institute (now part of the Natural Resources Institute Finland). Roger Jones kindly checked the English language.

Funding Open access funding provided by University of Helsinki including Helsinki University Central Hospital.

Data Availability The datasets generated during and analysed during the current study are available from the corresponding author on reasonable request.

Open Access This article is licensed under a Creative Commons Attribution 4.0 International License, which permits use, sharing, adaptation, distribution and reproduction in any medium or format, as long as you give appropriate credit to the original author(s) and the source, provide a link to the Creative Commons licence, and indicate if changes were made. The images or other third party material in this article are included in the article's Creative Commons licence, unless indicated otherwise in a credit line to the material. If material is not included in the article's Creative Commons licence and your intended use is not permitted by statutory regulation or exceeds the permitted use, you will need to obtain permission directly from the copyright holder. To view a copy of this licence, visit http://creativecommons.org/licenses/by/4.0/.

\section{References}

Ahonen, S. A., Hayden, B., Leppänen, J. J., \& Kahilainen, K. K. (2018). Climate and productivity affect total mercury concentration and bioaccumulation rate of fish along a spatial gradient of subarctic lakes. Science of the Total Environment, 637-638, 1586-1596.

Åkerblom, S., Bignert, A., Meili, M., Sonesten, L., \& Sundbom, M. (2014). Half a century of changing mercury levels in Swedish freshwater fish. Ambio, 43, 91-103.
Allen, K. R. (1935). The food and migration of perch (Perca fluviatilis) in Windermere. Journal of Animal Ecology, 4, 264-273.

Almer, B., Dickson, W., Ekström, C., Hörnström, E., \& Miller, U. (1974). Effects of acidification on Swedish lakes. Ambio, 3, 30-36.

Arvola, L., Salonen, K., Kankaala, P., \& Lehtovaara, A. (1992). Vertical distributions of bacteria and algae in a steeply stratified humic lake under high grazing pressure from Daphnia longispina. Hydrobiologia, 229, 253-269.

Arvola, L., Salonen, K., Keskitalo, J., Tulonen, T., Järvinen, M., \& Huotari, J. (2014). Plankton metabolism and sedimentation in a small boreal lake - a long-term perspective. Boreal Environment Research, 19(Suppl. A), 83-96.

Arvola, L., Rask, M., Forsius, M., Ala-Opas, P., Keskitalo, J., Kulo, K., et al. (2017). Food web responses to artificial mixing in a small boreal lake. Water, 9, 515. https://doi. org/10.3390/w9070515

Baker, J. P., Warren-Hicks, W. J., Gallagher, J., \& Christensen, S. W. (1993). Fish population losses from Adirondack lakes: The role of surface water acidity and acidification. Water Resources Research, 29, 861-874.

Björklund, I., Borg, H., \& Johansson, K. (1984). Mercury in Swedish lakes - its regional distribution and causes. Ambio, 13, 118-121.

Bloom, N. S., Watras, C. J., \& Hurley, J. P. (1991). Impact of acidification on the methylmercury cycle of remote seepage lakes. Water, Air, and Soil Pollution, 56, 477-491.

Braaten, H. F. V., deWit, H. A., Fjeld, E., Rognerud, S., Lydersen, E., \& Larssen, T. (2014a). Environmental factors influencing mercury speciation in subarctic and boreal lakes. Science of the Total Environment, 467-477, 336-345.

Braaten, H. F. V., Fjeld, E., Rognerud, S., Lund, E., \& Larssen, T. (2014b). Seasonal and year-to-year variation of mercury concentration in perch (Perca fluviatilis) in boreal lakes. Environmental Toxicology and Chemistry, 33, 2661-2670.

Braaten, H. F. V., de Wit, H. A., Larssen, T., \& Poste, A. E. (2018). Mercury in fish from Norwegian lakes: The complex influence of aqueous organic carbon. Science of the Total Environment, 627, 341-348.

Braaten, H. F. V., Åkerblom, S., Kahilainen, K. K., Rask, M., Vuorenmaa, J., Mannio, J., et al. (2019). Improved environmental status: 50 years of declining fish mercury levels in boreal and subarctic Fennoscandia. Environmental Science and Technology, 53, 1834-1843.

Braaten, H. F. V., Lindholm, M., \& de Wit, H. A. (2020). Five decades if declining methylmercury concentrations in boreal foodwebs suggest pivotal role for sulphate deposition. Science of the Total Environment, 714, 136774.

Chen, L., Zhang, W., Zhang, Y., Tong, Y., Liu, M., Wang, H., et al. (2018). Historical and future trends in global source-receptor relationships of mercury. Science of Total Environment, 610-611, 24-31.

Choi, S.-C., Chase, T., Jr., \& Bartha, R. (1994). Metabolic pathways leading to mercury methylation in Desulfovibrio desulfuricans LS. Applied and Environmental Microbiology, 60, 4072-4077.

Couture, R.-M., de Wit, H., Tominaga, K., Kiuru, P., \& Markelov, I. (2015). Oxygen dynamics in a boreal lake responds to long-term changes in climate, ice phenology, and DOC inputs. Journal of Geophysical Research : Biogeosciences., 120, 2441-2456. 
Creed, I. F., Bergström, A.-K., Trick, C. G., Grimm, N. B., Hessen, D. O., Karlsson, J., et al. (2018). Global changedriven effects on dissolved organic matter composition: Implications for food webs of northern lakes. Global Change Biology, 24, 3692-3714.

de Wit, H. A., Valinia, S., Weyhenmeyer, G. A., Futter, M. N., Kortelainen, P., Austnes, K., Hessen, D. O., et al. (2016). Current browning of surface waters will be further promoted by wetter climate. Environmental Science and Technology Letters, 12, 430-435.

Downs, S. G., MacLeod, C. L., \& Lester, J. N. (1998). Mercury in precipitation and its relation to bioaccumulation in fish: A literature review Water. Air, and Soil Pollution, 108, 149-187.

Driscoll, C. T., Blette, V., Yan, C., Schofield, C. L., Munson, R., \& Holsapple, J. (1995). The role of dissolved organic carbon in the chemistry and bioavailability of mercury in remote Adirondack lakes. Water, Air, and Soil Pollution, 80, 499-508.

Eckley, C. S., Watras, C. J., Hintelmann, H., Morrison, K., Kent, A. D., \& Regnell, O. (2005). Mercury methylation in the hypolimnetic waters of lakes with and without connection to wetlands in northern Wisconsin. Canadian Journal of Fisheries and Aquatic Sciences, 62, 400-411.

Eklöf, K., Bishop, K., Bertilsson, S., Björn, E., Buck, M., Skyllberg, U., et al. (2018). Formation of mercury methylation hotspots as a consequence of forestry operations. Science of the Total Environment, 613-614, 1069-1078.

Estlander, S., Nurminen, L., Olin, M., Vinni, M., Immonen, S., Rask, M., et al. (2010). Diet shift and food selection of (Perca fluviatilis) and roach (Rutilus rutilus) in humic lakes of varying water colour. Journal of Fish Biology, 77, 241-256.

Fjellheim, A., Tysse, A., \& Bjerknes, V. (2007). Fish stomachs as a biomonitoring tool in studies of invertebrate recovery. Water, Air, and Soil Pollution, Focus, 7, 293-300.

Forsius, M., Kämäri, J., Kortelainen, P., Mannio, J., Verta, M., \& Kinnunen, K. (1990). Statistical lake survey in Finland: Regional estimates of lake acidification. In P. Kauppi, P. Anttila, \& K. Kenttämies (Eds.), Acidification in Finland (pp. 759-780). Springer-Verlag.

Forsius, M., Saloranta, T., Arvola, L., Salo, S., Verta, M., Ala-Opas, P., et al. (2010). Physical and chemical consequences of artificially deepened thermocline in a small humic lake - a paired whole-lake climate change experiment. Hydrology \& Earth System Sciences, 14, 2629-2642.

Futter, M. N. (1994). Pelagic food-web structure influences probability of mercury contamination in lake trout (Salvelinus namaycush). Science of the Total Environment, 145, 7-12.

Gandhi, N., Tang, R. W. K., Bhavsar, S. P., \& Arhonditsis, G. B. (2014). Fish mercury levels appear to be increasing lately: A report from 40 years of monitoring in the province of Ontario, Canada. Environmental Science and Technology, 48, 5404-5414.

Greenfield, B. K., Hrabik, T. R., Harvey, C. J., \& Carpenter, S. R. (2001). Predicting mercury levels in yellow perch: Use of water chemistry, trophic ecology, and spatial traits. Canadian Journal of Fisheries and Aquatic Sciences, 58, 1419-1429.

Göthberg, A. (1983). Intensive Fishing - a way to reduce the mercury level in fish. Ambio, 12, 259-261.

Häsänen, E. \& Sjöblom, V. (1968). Kalojen elohopeapitoisuus Suomessa vuonna 1967 (Mercury concentrations of fish in Finland in 1967). Suomen kalatalous 36, 1-24. (in Finnish, with an English summary)

Henriksen, A., Skjelkvåle, B., Mannio, J., Wilander, A., Harriman, R., Curtis, C., et al. (1998). Northern European lake survey, 1995. Ambio, 27, 80-91.

Hesthagen, T., Sevaldrud, I. H., \& Berger, H. M. (1999). Assessment of damage to fish populations in Norwegian lakes due to acidification. Ambio, 28, 112-117.

Hongve, D., Haaland, S., Riise, G., Blakar, I., \& Norton, S. (2012). Decline of acid rain enhances mercury concentrations in fish. Environmental Science and Technology, 46, 2490-2491.

Hrabik, T. R., \& Watras, C. J. (2002). Recent declines in mercury concentration in a freshwater fishery isolating the effects of de-acidification and decreased atmospheric mercury deposition in Little Rock Lake. Science of the Total Environment, 297, 229-237.

Ilyin I., Rozovskaya O., Travnikov O. \& Varygina M. (2015). Heavy metals: Analysis of long-term trends, countryspecific research and progress in mercury regional and global modelling. EMEP Status Report 2/2015

Jylhä, K., Laapas, M., Ruosteenoja, K., Arvola, L., Drebs, A., Kersalo, J. et al. (2014). Climate variability and trends in the Valkea-Kotinen region, southern Finland: comparisons between the past, current and projected climates. Boreal Environment Research 19 (Suppl. A), 4-30

Kahilainen, K. K., Thomas, S. M., Keva, O., Hayden, B., Knudsen, R., Eloranta, A. P., et al. (2016). Seasonal dietary shift to zooplankton influences stable isotope ratios and total mercury concentrations in Arctic charr (Salvelinus alpinus (L.)). Hydrobiologia, 783, 47-63.

Kainz, M., \& Lucotte, M. (2006). Mercury concentrations in lake sediments - Revisiting the predictive power of catchment morphometry and organic matter composition. Water, Air, and Soil Pollution, 170, 173-189.

Karhunen, J., Arvola, L., Peura, S., \& Tiirola, M. (2013). Green sulphur bacteria as a component of the photosynthetic plankton community in small dimictic humic lakes with an anoxic hypolimnion. Aquatic Microbial Ecology, 68, 267-272.

Karimi, R., Chen, C. Y., \& Folt, C. L. (2016). Comparing nearshore benthic and pelagic prey as mercury sources to lake fish: The importance of prey quality and mercury content. Science of the Total Environment, 565, 211-221.

Keller, W., Yan, N. D., Gunn, J. M., \& Heneberry, J. (2007). Recovery of acidified lakes: Lessons from Sudbury, Ontario, Canada. Water, Air, and Soil Pollution: Focus, 7, 317-322.

Keva, O., Hayden, B., Harrod, C., \& Kahilainen, K. K. (2017). Total mercury concentrations in liver and muscle of European whitefish (Coregonus lavaretus (L.)) in a subarctic lake - assessing the factors driving year-round variation. Environmental Pollution, 231, 1518-1528.

Kraemer, L. T., Evans, D., \& Dillon, P. J. (2012). The impacts of ontogenetic dietary shifts in yellow perch (Perca 
flavescens) on $\mathrm{Zn}$ and $\mathrm{Hg}$ accumulation. Ecotoxicology and Environmental Safety, 78, 246-252.

Lappalainen, A., Rask, M., \& Vuorinen, P. (1988). Acidification affects the perch, Perca fluviatilis L., populations in small lakes of southern Finland. Environmental Biology of Fishes, 21, 231-239.

Lescord, G. L., Johnston, T. A., Branfireun, B. A., \& Gunn, J. M. (2018). Percentage of methylmercury in the muscle tissue of freshwater fish varies with body size and age and among species. Environmental Toxicology and Chemistry, 37, 2682-2691.

Lodenius, M. (1991). Mercury concentrations in an aquatic ecosystem during twenty years following abatement the pollution source. Water, Air, and Soil Pollution, 56, 323-332.

Mannio, J. (2001). Responses of headwater lakes to air pollution changes in Finland. Monographs of the Boreal Environment Research No. 18. Finnish Environment Institute

Marttila, J. \& Roikonen, T. (2016). Ahventen elohopeapitoisuuden seuranta Uudellamaalla 2010-2014. Centre for Economic Development, Transport and the Environment for Lapland. Raportteja 79/2016. 14 p. (in Finnish)

Metsälä, T., \& Rask, M. (1989). Mercury concentrations of perch, Perca fluviatilis L., in small Finnish headwater lakes with different $\mathrm{pH}$ and water colour. Aqua Fennica, $19,41-46$.

Monteith, D. T., Stoddard, J. L., Evans, C. D., de Wit, H. A., Forsius, M., Høgåsen, T., et al. (2007). Dissolved organic carbon trends resulting from changes in atmospheric deposition chemistry. Nature, 450, 537-540.

Morel, F. M. M., Kraepiel, A. M. L., \& Amyot, M. (1998). The chemical cycle and bioaccumulation of mercury. Annual Reviews of Ecology and Systematics, 29, 543-566.

Nurminen, L., Hellén, N., Olin, M., Tiainen, J., Vinni, M., Grönroos, M., et al. (2018). Fishing -induced changes in predation pressure by perch (Perca fluviatilis) regulate littoral benthic macroinvertebrate biomass, density, and community structure. Aquatic Ecology, 52, 1-16. https:// doi.org/10.1007/s10452-017-9641-4

Nyberg, K., Raitaniemi, J., Rask, M., Mannio, J., \& Vuorenmaa, J. (1995). What can perch population data tell us about the acidification history of a lake? Water, Air, and Soil Pollution, 85, 395-400.

Nyberg, K., Vuorenmaa, J., Tammi, J., Nummi, P., Väänänen, V.-M., Mannio, J., et al. (2010). Re-establishment of perch in three lakes recovering from acidification: Rapid growth associated with abundant food resources. Boreal Environment Research, 15, 480-490.

Olin, M., Rask, M., Ruuhijärvi, J., Keskitalo, J., Horppila, J., Tallberg, P., et al. (2006). Effects of biomanipulation on plankton and fish communities in ten eutrophic lakes in southern Finland. Hydrobiologia, 553, 67-88.

Olin, M., Tiainen, J., Rask, M., Vinni, M., Nyberg, K., \& Lehtonen, H. (2017). Effects of non-selective and sizeselective fishing on perch populations in a small lake. Boreal Environment Research, 22, 137-155.

Pacyna, E. G., Pacyna, J. M., Sundseth, K., Munthe, J., Kindbom, K., Wilson, S., et al. (2010). Global emission of mercury to the atmosphere from anthropogenic sources in 2005 and projections to 2020. Atmospheric Environment, 44, 2487-2499.
Paloheimo, A. (2005). Hauen (Esox Lucius L.) elohopeapitoisuuteen ja pitoisuuden muutokseen vaikuttavat ympäristötekijät (Environmental factors affecting the changes in mercury concentrations of pike (Esox lucius L.)) M. Sci. thesis, Department of Environmental Sciences, University of Helsinki, 76 p. (In Finnish)

Parkman, H., \& Meili, M. (1993). Mercury in macroinvertebrates from Swedish forest lakes: Influence of lake type, habitat, life cycle, and food quality. Canadian Journal of Fisheries and Aquatic Sciences, 50, 521-534.

Porvari, P. (1998). Development of fish mercury concentrations in Finnish reservoirs from 1979 to 1994. Science of the Total Environment, 213, 279-290.

Raitaniemi, J., Rask, M., \& Vuorinen, P. J. (1988). The growth of perch, Perca fluviatilis L., in small Finnish lakes at different stages of acidification. Annales Zoologici Fennici, 25, 209-219.

Rask, M., \& Tuunainen, P. (1990). Acid-induced changes in fish populations of small Finnish lakes. In P. Kauppi, P. Anttila, \& K. Kenttämies (Eds.), Acidification in Finland (pp. 911-927). Springer-Verlag.

Rask, M., Vuorinen, P. J., \& Vuorinen, M. (1990). Delayed spawning of perch, Perca fluviatilis L., in acidified lakes. Journal of Fish Biology, 36, 317-325.

Rask, M., Mannio, J., Forsius, M., Posch, M., \& Vuorinen, P. J. (1995). How many fish populations in Finland are affected by acid precipitation. Environmental Biology of Fishes, 42, 51-63.

Rask, M., Järvinen, M., Kuoppamäki, K., \& Pöysä, H. (1996). Limnological responses to the collapse of the perch population in a small lake. Annales Zoologici Fennici, 33, 517-524.

Rask, M., Pöysä, H., Nummi, P., \& Karppinen, C. (2001). Recovery of the perch (Perca fluviatilis) in an acidified lake and subsequent responses in macroinvertebrates and the goldeneye (Bucephala clangula). Water, Air, and Soil Pollution, 130, 1367-1372.

Rask, M., Jones, R. I., Järvinen, M., Paloheimo, A., Salonen, M., Syväranta, J., et al. (2007). Changes in fish mercury concentrations over 20 years in an acidified lake subject to experimental liming. Applied Geochemistry, 22, 1229-1240.

Rask, M., Verta, M., Korhonen, M., Salo, S., Forsius, M., Arvola, L., Jones, R. I., et al. (2010). Does lake thermocline depth affect methyl mercury concentrations in fish? Biogeochemistry, 101, 311-322.

Rask, M., Vuorenmaa, J., Nyberg, K., Tammi, J., Mannio, J., Olin, M., et al. (2014a). Recovery of acidified lakes in Finland and subsequent responses of perch and roach populations. Boreal Environment Research, 19, 222-234.

Rask, M., Sairanen, S., Vesala, S., Arvola, L., Estlander, S. \& Olin, M. (2014b). Population dynamics and growth of perch in a small, humic lake over a 20-year period - importance of abiotic and biotic factors. Boreal Environment Research 19 Supplement A 2014, $112-123$

Richman, L. A., Wren, C. D., \& Stokes, P. M. (1988). Facts and fallacies concerning mercury uptake by fish in acid stressed lakes. Water, Air, and Soil Pollution, 37, 465-473. 
Rudd, J. W. M. (1995). Sources of methylmercury to aquatic ecosystems: A review. Water, Air, and Soil Pollution, 80, 697-713.

Ruoho-Airola, T., Hatakka, T., Kyllönen, K. Makkonen, U. \& Porvari, P. (2014). Temporal trends in the bulk depositionmnand atmospheric concentration of acidifying compounds and trace metals in the Finnish Integrated Monitoring catchment Valkea-Kotinen during 1988-2011. Boreal Environment Research 19 Supplement A 2014, 31-46.

Simonin, H. A., Loukmas, J. J., Skinner, L. C., \& Roy, K. M. (2008). Lake variability: Key factors controlling mercury concentrations in New York State fish. Environmental Pollution, 154, 107-115.

Stoddard, J. L., Jeffries, D. S., Lükewille, A., Clair, T., Dillon, P. J., Driscoll, C. T., et al. (1999). Regional trends in aquatic recovery from acidification in North America and Europe. Nature, 401, 575-578.

Streets, D. G., Devane, M. K., Lu, Z., Bond, T. C., Sunderland, E. M., \& Jacob, D. J. (2011). All-time releases of mercury to the atmosphere from human activities. Environmental Science and Technology, 45, 10485-10491.

Tammi, J., Appelberg, M., Hesthagen, T., Beier, U., Lappalainen, A., \& Rask, M. (2003). Fish status survey of Nordic lakes: Effects of acidification, eutrophication and stocking activity on present fish species composition. Ambio, 32, 98-105.

Tammi, J., Rask, M., Vuorenmaa, J., Lappalainen, A., \& Vesala, S. (2004). Population responses of perch (Perca fluviatilis) and roach (Rutilus rutilus) to recovery from acidification in small Finnish lakes. Hydrobiologia, 528, 107-122.

Travnikov, O., Ilyin, I., Rozovskaya, O., Varygina, M., Aas, W., Uggerud, H.T. et al. (2012). Long-term changes of heavy metal transboundary pollution of the environment (19902010). EMEP contribution to the revision of the Heavy Metal Protocol. EMEP MSC-E \& CCC \& CEIP Status Report 2/2012

Ullrich, S. M., Tanton, T. W., \& Abdrashitova, S. A. (2001). Mercury in the aquatic environment: A review of factors affecting methylation. Critical Reviews in Environmental Science and Technology, 31, 241-293.

Verta, M. (1990a). Mercury in Finnish forest lakes and reservoirs: Anthropogenic contribution to the load and accumulation in fish. $\mathrm{PhD}$ thesis, University of Helsinki

Verta, M. (1990b). Changes in fish mercury concentrations in an intensively fished lake. Canadian Journal of Fisheries and Aquatic Sciences, 47, 1888-1897.

Verta, M., Mannio, J., Iivonen, P., Hirvi, J.-P., Järvinen, O., \& Piepponen, S. (1990). Trace metals in Finnish headwater lakes - effects of acidification and airborne load. In P. Kauppi, P. Anttila, \& K. Kenttämies (Eds.), Acidification in Finland (pp. 883-908). Springer-Verlag.

Verta, M., Salo, S., Korhonen, M., Porvari, P., Paloheimo, A., \& Munthe, J. (2010). Climate induced thermocline change has an effect on methyl mercury cycle in small boreal lakes. Science of the Total Environment, 408, 3639-3647.

Vuorenmaa, J., \& Forsius, M. (2008). Recovery of acidified Finnish lakes: Trends, patterns and dependence of catchment characteristics. Hydrology \& Earth System Sciences, 12, 465-478.
Vuorenmaa, J., Forsius, M., \& Mannio, J. (2006). Increasing trends in total organic carbon concentrations in small forest lakes in Finland from 1987 to 2003. Science of the Total Environment, 365, 47-65.

Vuorenmaa, J., Salonen, K., Arvola, L., Mannio, J., Rask, M. \& Horppila, P. (2014). Water quality of a small headwater lake reflects long-term variations in deposition, climate and in-lake processes. Boreal Environment Research 19 (suppl. A), 47-65

Vuorinen, P. J., Vuorinen, M., Peuranen, S., Lappalainen, A., \& Rask, M. (1992). Reproductive status, blood chemistry, gill histology and growth of perch (Perca fluviatilis L.) in three acidic lakes. Environmental Pollution, 78, 19-27.

Wang, F., Outridge, P. M., Feng, X., Meng, B., HeimbürgerBoavida, L.-E., \& Mason, R. P. (2019). How closely do mercury trends in fish and other aquatic wildlife track those in the atmosphere? - implications for evaluating the effectiveness of the Minamata Convention. Science of the Total Environment, 674, 58-70.

Watras, C. J., Morrison, K. A., \& Host, J. S. (1995). Concentration of mercury species in relationship to other site-specific factors in the surface waters of northern Wisconsin lakes. Limnology \& Oceanography, 40, 556-565.

Watras, C. J., Back, R. C., Halvorsen, S., Hudson, R. J. M., Morrison, K. A., \& Wente, S. P. (1998). Bioaccumulation of mercury in pelagic freshwater food webs. Science of the Total Environment, 219, 183-208.

Watras, C. J., Morrison, K. A., Regnell, O., \& Kratz, T. K. (2006). The methylmercury cycle in Little Rock Lake during experimental acidification and recovery. Limnology \& Oceanography, 51, 257-270.

Watras, C. J., Grande, D., Latzka, A. W., \& Tate, L. S. (2019). Mercury trends and cycling in northern Wisconsin related to atmospheric and hydrological processes. Canadian Journal of Fisheries and Aquatic Sciences, 76, 831-846.

Watras, C. J., Teng, H.-Y., Latzka, A. W., Meyer, M. W., \& Zhang, Z. (2020). Near-decadal oscillation of water levels and mercury bioaccumulation in the Laurentian Great Lakes Region. Environmental Science and Technology Letters, 7, 89-94.

Wängberg, I., Aspmo Pfaffhuber, K., Berg, T., Hakola, H., Kyllönen, K., Munthe, J., et al. (2010). Atmospheric and catchment mercury concentrations and fluxes in Fennoscandia. TemaNord, 2010(594), 1-56.

Wyn, B., Kidd, K. A., Burgess, N. M., Curry, R. A., \& Munkittrick, K. R. (2010). Increasing mercury in yellow perch at a hotspot in Atlantic Canada, Kejimkujik National Park. Environmental Science and Technology, 44, 9176-9181.

Yu, X., Driscoll, C. T., Montesdeoca, M., Evers, D., Duron, M., Williams, K., et al. (2011). Spatial patterns of mercury in biota of Adirondack, New York lakes. Ecotoxicology, 20, 1543-1554.

Zwart, J. A., Sebestyen, S. D., Solomon, C. T., \& Jones, S. E. (2017). The influence of hydrologic residence time on lake carbon cycling dynamics following extreme precipitation events. Ecosystems, 20, 1000-1014.

Publisher's Note Springer Nature remains neutral with regard to jurisdictional claims in published maps and institutional affiliations. 